\title{
$P$-wave velocity test for assessment of geotechnical properties of some rock materials
}

\author{
SAFFET YAGIZ \\ Faculty of Engineering, Department of Geological Engineering, Pamukkale University, Denizli, Turkey
}

MS received 9 September 2009; revised 11 July 2010

\begin{abstract}
P$-wave velocity test, a non-destructive and easy method to apply in both field and laboratory conditions, has increasingly been conducted to determine the geotechnical properties of rock materials. The aim of this study is to predict the rock properties including the uniaxial compressive strength, Schmidt hardness, modulus of elasticity, water absorption and effective porosity, slake durability index, saturated and dry density of rock using $P$-wave velocity $\left(V_{\mathrm{p}}\right)$. For this purpose geotechnical properties of nine different rock types were determined in the laboratory and their mineralogical composition examined using thin section analysis. Utilizing the generated data, sets of empirical equations were developed between $V_{p}$ and relevant quantified rock parameters. The validity of the obtained empirical equations was confirmed using statistical analysis. It is evident that rock texture and mineralogical compositions affect the geotechnical properties of rock materials. Therefore, the best relationship obtained between both $E$ and UCS with $V_{p}$ in the correlation coefficient of 0.92 and 0.95 in that order. It is concluded that $V_{\mathrm{p}}$ could be practically used for estimating the measured rock properties except dry and saturated density of rocks $(r=0.58$ and 0.46 respectively).
\end{abstract}

Keywords. Empirical equations; $P$-wave velocity; regression analysis; rock properties.

\section{Introduction}

$P$-wave velocity test that can be carried out both in the laboratory and on-site is a common non-destructive testing method used in civil, geotechnical and mining projects such as underground opening, quarrying, blasting and ripping. Seismic techniques can be used for predicting the rock mass deformation and stress as well as extend of damage zone developed around the underground opening and tunnels (Onodera 1963; Hudson et al 1980; Gladwin 1982). The method is also commonly used for determination of rock weathering degree and rock mass characterization (Turk and Dearman 1986; Karpuz and Pasamehmetoglu 1997; Boadu 1997). Thill and Bur (1969) stated that the $P$-wave velocity changes with porosity and degree of saturation. Lama and Vutukuri (1978) indicated that the wetting of rock usually leads to a rise in the $P$-wave velocity. Several researchers (Hawkins and McConnell 1992; Ulusay et al 1994; Tugrul and Zarif 1999; Kahraman 2001; Yasar and Erdogan 2004; Kahraman and Yeken 2008; Sharma and Singh 2007; Yagiz 2009) reported that the $V_{\mathrm{p}}$ has relationship with some rock properties such as uniaxial compressive strength, hardness, density and slake durability index of rock as shown in table 1 . However, obtained correlations

(syagiz@pau.edu.tr) are not constant and can be varied with rock types. This paper attempts to investigate the empirical relationship between $V_{\mathrm{p}}$ and rock properties including the uniaxial compressive strength (UCS), modulus of elasticity (E), Schmidt hardness $(\mathrm{Hr})$, slake durability index $\left(\mathrm{Id}_{2}\right)$, effective porosity $\left(n^{\prime}\right)$, water absorption by weight $(w)$, and both saturated $\left(\rho_{\text {sat }}\right)$ and dry $\left(\rho_{\text {dry }}\right)$ density of rocks. Further, obtained results are also compared with previous studies in the literature.

\section{Rock sampling and laboratory tests}

Rock blocks were collected from various stone quarries located around the cities of Denizli and Antalya in southwestern Turkey (figure 1). Nine different rocks consisting of four types of travertine, three types of limestone and two types of schist were collected from the study area. Each rock block was inspected to ensure that it would provide standard testing specimens without macroscopic defects, alteration zones and fractures. Following the European Norms (EN 2000a, b) and ISRM (1981) suggested methods, relevant rock properties i.e. $V_{\mathrm{p}}$, UCS, $\mathrm{E}, \mathrm{Hr}, \mathrm{Id}_{2}, n^{\prime}, w, \rho_{\text {sat }}$ and $\rho_{\text {dry }}$ were determined. For each test, 10 rock samples were prepared. The average values obtained along with the standard deviation are given in table 2. Entire tests were performed on intact rock samples. If a rock failed along the anisotropy zone or weak- 
Table 1. Relationship between $V_{\mathrm{p}}$ with both $\rho$ and UCS.

\begin{tabular}{|c|c|c|c|c|c|}
\hline Researchers & Equations & $r$ value & $\begin{array}{l}\text { Rock type/ } \\
\text { lithology }\end{array}$ & $\begin{array}{c}\mathrm{UCS}(\mathrm{MPa}) \\
\rho\left(\mathrm{g} / \mathrm{cm}^{3}\right)\end{array}$ & $V_{\mathrm{p}}(\mathrm{km} / \mathrm{s})$ \\
\hline Tugrul and Zarif (1999) & $\mathrm{UCS}=35 \cdot 54 \cdot V_{\mathrm{p}}-55$ & $0 \cdot 80$ & Igneous rocks & $100-200$ & $4 \cdot 5-6 \cdot 5$ \\
\hline Kahraman (2001) & $\mathrm{UCS}=9 \cdot 95 \cdot V_{\mathrm{p}}^{1 \cdot 21}$ & $0 \cdot 83$ & Limestone, marble & $10-160$ & $1 \cdot 2-6 \cdot 4$ \\
\hline \multirow[t]{2}{*}{ Yasar and Erdogan (2004) } & $\mathrm{UCS}=\left(V_{\mathrm{p}}-2 \cdot 0195\right) / 0 \cdot 032$ & $0 \cdot 81$ & \multirow[t]{2}{*}{ Lime, marble, dolomite } & $38-120$ & $2 \cdot 9-5 \cdot 6$ \\
\hline & $\rho=\left(V_{\mathrm{p}}+7 \cdot 707\right) / 4 \cdot 3183$ & $0 \cdot 80$ & & $2 \cdot 43-2 \cdot 97$ & $2 \cdot 9-5 \cdot 6$ \\
\hline \multirow[t]{2}{*}{ Sharma and Singh (2007) } & $\mathrm{UCS}=0 \cdot 0642 \cdot V_{\mathrm{p}}-117.99$ & $0 \cdot 90$ & \multirow[t]{2}{*}{7 types of rocks } & $10-1970$ & $2-3.2 .0$ \\
\hline & $\mathrm{Id}_{2}=0 \cdot 069 \cdot V_{\mathrm{p}}+78.577$ & $0 \cdot 88$ & & - & - \\
\hline Kahraman and Yeken (2008) & $\rho=0 \cdot 213 \cdot V_{\mathrm{p}}+1 \cdot 256$ & $0 \cdot 82$ & Carbonate rocks & $2 \cdot 0-2 \cdot 6$ & $3 \cdot 6-6 \cdot 1$ \\
\hline \multirow[t]{4}{*}{ This study } & $\mathrm{UCS}=0 \cdot 258 \cdot V_{\mathrm{p}}^{3 \cdot 543}$ & 0.92 & \multirow[t]{4}{*}{9 types of rock } & $20-125$ & $1 \cdot 89-6 \cdot 1$ \\
\hline & $\mathrm{UCS}=49 \cdot 4 \cdot V_{\mathrm{p}}-167$ & $0 \cdot 89$ & & - & \\
\hline & $\rho=0 \cdot 19 \cdot V_{\mathrm{p}}+1 \cdot 61$ & 0.58 & & $2 \cdot 15-2 \cdot 85$ & $1 \cdot 8-6 \cdot 1$ \\
\hline & $\mathrm{Id}_{2}=0 \cdot 71 \cdot V_{\mathrm{p}}+95 \cdot 7$ & 0.69 & & - & - \\
\hline
\end{tabular}

*UCS = uniaxial compressive strength $(\mathrm{MPa}), V_{\mathrm{p}}=P$-wave velocity $(\mathrm{km} / \mathrm{s}), \rho=\operatorname{density}\left(\mathrm{g} / \mathrm{cm}^{3}\right)$

Table 2. Geotechnical properties of studied rock units based on averaged properties and standard deviation.

\begin{tabular}{|c|c|c|c|c|c|c|c|c|c|c|}
\hline $\begin{array}{l}\text { Sampling } \\
\text { locations }\end{array}$ & $\begin{array}{l}\text { Rock } \\
\text { type }\end{array}$ & $\begin{array}{c}V_{\mathrm{p}} \\
\pm \mathrm{SD} \\
(\mathrm{km} / \mathrm{s})\end{array}$ & $\begin{array}{c}\mathrm{Hr} \\
\bar{x} \pm \mathrm{SD} \\
-\end{array}$ & $\begin{array}{c}\mathrm{UCS} \\
\bar{x} \pm \mathrm{SD} \\
(\mathrm{MPa})\end{array}$ & $\begin{array}{c}E \\
\bar{x} \pm \mathrm{SD} \\
(\mathrm{GPa})\end{array}$ & $\begin{array}{c}n^{\prime} \\
\bar{x} \pm \mathrm{SD} \\
(\%)\end{array}$ & $\begin{array}{c}w \\
\bar{x} \pm \mathrm{SD} \\
(\%)\end{array}$ & $\begin{array}{c}\rho_{\text {dry }} \\
\bar{x} \pm \mathrm{SD} \\
\left(\mathrm{g} / \mathrm{cm}^{3}\right)\end{array}$ & $\begin{array}{c}\rho_{\text {sat }} \\
\bar{x} \pm \mathrm{SD} \\
\left(\mathrm{g} / \mathrm{cm}^{3}\right)\end{array}$ & $\begin{array}{c}\mathrm{Id}_{2} \\
\bar{x} \pm \mathrm{SD} \\
(\%)\end{array}$ \\
\hline Denizli/Kocabas & $\begin{array}{l}\text { Shrub } \\
\text { travertine }\end{array}$ & $\begin{array}{l}4 \cdot 8 \pm \\
0 \cdot 12\end{array}$ & $\begin{array}{l}45 \pm \\
4 \cdot 5\end{array}$ & $\begin{array}{l}61 \pm \\
20 \cdot 6\end{array}$ & $\begin{array}{l}43 \pm \\
6 \cdot 9\end{array}$ & $\begin{array}{l}1 \cdot 35 \pm \\
0.46\end{array}$ & $\begin{array}{l}0 \cdot 55 \pm \\
0 \cdot 19\end{array}$ & $\begin{array}{l}2 \cdot 474 \pm \\
0 \cdot 25\end{array}$ & $\begin{array}{l}2 \cdot 488 \pm \\
0 \cdot 22\end{array}$ & $\begin{array}{l}98.91 \pm \\
0 \cdot 10\end{array}$ \\
\hline Denizli/Kocabas & $\begin{array}{l}\text { Noche } \\
\text { travertine }\end{array}$ & $\begin{array}{l}5 \cdot 0 \pm \\
0 \cdot 08\end{array}$ & $\begin{array}{l}47 \pm \\
3 \cdot 1\end{array}$ & $\begin{array}{l}64 \pm \\
10 \cdot 9\end{array}$ & $\begin{array}{l}44 \pm \\
3 \cdot 3\end{array}$ & $\begin{array}{l}1.59 \pm \\
0.89\end{array}$ & $\begin{array}{l}0 \cdot 66 \pm \\
0 \cdot 38\end{array}$ & $\begin{array}{l}2 \cdot 419 \pm \\
0 \cdot 48\end{array}$ & $\begin{array}{l}2 \cdot 435 \pm \\
0 \cdot 42\end{array}$ & $\begin{array}{l}98.55 \pm \\
0 \cdot 14\end{array}$ \\
\hline Denizli/Kaklık & $\begin{array}{l}\text { Reed } \\
\text { travertine }\end{array}$ & $\begin{array}{l}4 \cdot 5 \pm \\
0 \cdot 11\end{array}$ & $\begin{array}{l}39 \pm \\
4 \cdot 7\end{array}$ & $\begin{array}{l}41 \pm \\
16 \cdot 6\end{array}$ & $\begin{array}{l}35 \pm \\
5 \cdot 8\end{array}$ & $\begin{array}{l}1 \cdot 89 \pm \\
0.50\end{array}$ & $\begin{array}{l}0 \cdot 80 \pm \\
0 \cdot 22\end{array}$ & $\begin{array}{l}2 \cdot 362 \pm \\
0 \cdot 56\end{array}$ & $\begin{array}{l}2 \cdot 381 \pm \\
0 \cdot 54\end{array}$ & $\begin{array}{l}98 \cdot 87 \pm \\
0 \cdot 12\end{array}$ \\
\hline Denizli/Honaz & $\begin{array}{l}\text { Onyx } \\
\text { travertine }\end{array}$ & $\begin{array}{l}4 \cdot 7 \pm \\
0 \cdot 19\end{array}$ & $\begin{array}{l}51 \pm \\
3 \cdot 3\end{array}$ & $\begin{array}{l}58 \pm \\
15\end{array}$ & $\begin{array}{l}44 \pm \\
5 \cdot 2\end{array}$ & $\begin{array}{l}2 \cdot 05 \pm \\
0 \cdot 88\end{array}$ & $\begin{array}{l}0 \cdot 76 \pm \\
0 \cdot 34\end{array}$ & $\begin{array}{l}2 \cdot 715 \pm \\
0.46\end{array}$ & $\begin{array}{l}2 \cdot 735 \pm \\
0 \cdot 38\end{array}$ & $\begin{array}{l}99 \cdot 24 \pm \\
0 \cdot 07\end{array}$ \\
\hline Antalya/Korkuteli & $\begin{array}{l}\text { Beige } \\
\text { lime }\end{array}$ & $\begin{array}{l}5 \cdot 0 \pm \\
0 \cdot 17\end{array}$ & $\begin{array}{l}54 \pm \\
1.9\end{array}$ & $\begin{array}{l}82 \pm \\
28 \cdot 3\end{array}$ & $\begin{array}{l}46 \pm \\
4 \cdot 0\end{array}$ & $\begin{array}{l}0 \cdot 16 \pm \\
0 \cdot 10\end{array}$ & $\begin{array}{l}0.06 \pm \\
0.04\end{array}$ & $\begin{array}{l}2 \cdot 682 \pm \\
0 \cdot 08\end{array}$ & $\begin{array}{l}2 \cdot 683 \pm \\
0 \cdot 08\end{array}$ & $\begin{array}{l}99.43 \pm \\
0.04\end{array}$ \\
\hline Denizli/Bozkurt & $\begin{array}{l}\text { Dolomitic } \\
\text { lime }\end{array}$ & $\begin{array}{l}4 \cdot 9 \pm \\
0 \cdot 29\end{array}$ & $\begin{array}{l}53 \pm \\
2 \cdot 4\end{array}$ & $\begin{array}{l}92 \pm \\
33 \cdot 3\end{array}$ & $\begin{array}{l}52 \pm \\
11 \cdot 8\end{array}$ & $\begin{array}{l}0 \cdot 60 \pm \\
0 \cdot 27\end{array}$ & $\begin{array}{l}0 \cdot 22 \pm \\
0 \cdot 10\end{array}$ & $\begin{array}{l}2 \cdot 778 \pm \\
0 \cdot 34\end{array}$ & $\begin{array}{l}2 \cdot 784 \pm \\
0 \cdot 32\end{array}$ & $\begin{array}{l}99.65 \pm \\
0.06\end{array}$ \\
\hline Antalya/Elmali & $\begin{array}{l}\text { Soft } \\
\text { lime }\end{array}$ & $\begin{array}{l}3 \cdot 8 \pm \\
0 \cdot 41\end{array}$ & $\begin{array}{l}41 \pm \\
3 \cdot 6\end{array}$ & $\begin{array}{l}32 \pm \\
3 \cdot 7\end{array}$ & $\begin{array}{l}22 \pm \\
4 \cdot 7\end{array}$ & $\begin{array}{l}9 \cdot 70 \pm \\
2 \cdot 20\end{array}$ & $\begin{array}{l}4 \cdot 24 \pm \\
1 \cdot 14\end{array}$ & $\begin{array}{l}2 \cdot 311 \pm \\
0.98\end{array}$ & $\begin{array}{l}2.408 \pm \\
0.78\end{array}$ & $\begin{array}{l}98.49 \pm \\
0.25\end{array}$ \\
\hline Denizli/Bekilli & $\begin{array}{l}\text { Biotite } \\
\text { schist }\end{array}$ & $\begin{array}{l}5 \cdot 1 \pm \\
0 \cdot 44\end{array}$ & $\begin{array}{l}58 \pm \\
4 \cdot 4\end{array}$ & $\begin{array}{l}98 \pm \\
7 \cdot 1\end{array}$ & $\begin{array}{l}51 \pm \\
7 \cdot 9\end{array}$ & $\begin{array}{l}0 \cdot 74 \pm \\
0 \cdot 11\end{array}$ & $\begin{array}{l}0 \cdot 29 \pm \\
0 \cdot 04\end{array}$ & $\begin{array}{l}2 \cdot 547 \pm \\
0 \cdot 42\end{array}$ & $\begin{array}{l}2 \cdot 554 \pm \\
0 \cdot 43\end{array}$ & $\mathrm{n} / \mathrm{a}$ \\
\hline Denizli/Baklan & $\begin{array}{l}\text { Mica } \\
\text { schist }\end{array}$ & $\begin{array}{l}5 \cdot 6 \pm \\
0 \cdot 32\end{array}$ & $\begin{array}{l}59 \pm \\
1 \cdot 1\end{array}$ & $\begin{array}{l}114 \pm \\
13 \cdot 4\end{array}$ & $\begin{array}{l}57 \pm \\
6 \cdot 8\end{array}$ & $\begin{array}{l}0.43 \pm \\
0.53\end{array}$ & $\begin{array}{l}0 \cdot 17 \pm \\
0 \cdot 21\end{array}$ & $\begin{array}{l}2.638 \pm \\
0.72\end{array}$ & $\begin{array}{l}2 \cdot 642 \pm \\
0.67\end{array}$ & $\mathrm{n} / \mathrm{a}$ \\
\hline
\end{tabular}

$\bar{x}=$ Average values and $\mathrm{SD}=$ Standard deviation.

ness plane, the results were excluded. $V_{\mathrm{p}}$ is measured on samples by direct transmission using a Portable Ultrasonic Nondestructive Digital Indicating Tester (PUNDIT) that measures the time of propagation of ultrasound pulses with a precision of $0 \cdot 1 \mu \mathrm{s}$ and its transducers were $42 \mathrm{~mm}$ in diameter with $54 \mathrm{kHz}$ (figure 2). $V_{\mathrm{p}}$ test was performed perpendicular to observed layers. The $P$-wave velocity of studied rocks ranges from $3 \cdot 8-5 \cdot 1 \mathrm{~km} / \mathrm{s}$ and can be classified as shown in table 3 .

\section{Mineralogical composition of rock materials}

Block rocks including travertine, limestone and schist were collected from various rock quarries in southwestern Turkey (figure 3). Mineralogical and textural studies were conducted on prepared thin section samples using optical microscope in accordance with EN 12407 (2002) Standard (table 4). Travertine, from Quaternary to Neogene ages, is one of the most common carbonate 
rocks in the area. Travertine precipitated at different depositional conditions shows variations of colour, appearance, bedding, porosity, texture and composition (Chafetz and Folk 1984; Yagiz 2010). Travertine litho types in the basin mainly include shrub, onyx, reed and noche. Shrub type travertine represented by small bush like growths in the field is a common deposit on horizontal and sub horizontal surface in the basin (figure 3a). Noche, a commercial name for compact and dense reed type travertine is dark brownish in colour, dense and low porous (figure $3 \mathrm{~b}$ ). Reed travertine is one of the prominent elements in the study area and rich in molds of reed and coarse grass as in figure 3c (Guo and Riding 1998). Onyx travertine is commonly formed as a result of rapid precipitation due to fast flowing water on gentle slope. Dense, crudely fibrous and light coloured one is composed of elongated calcite feathers and developed perpendicular to the depositional surface (figure $3 \mathrm{~d}$ ). Jurassic aged beige coloured crystalline limestone and Eocene aged

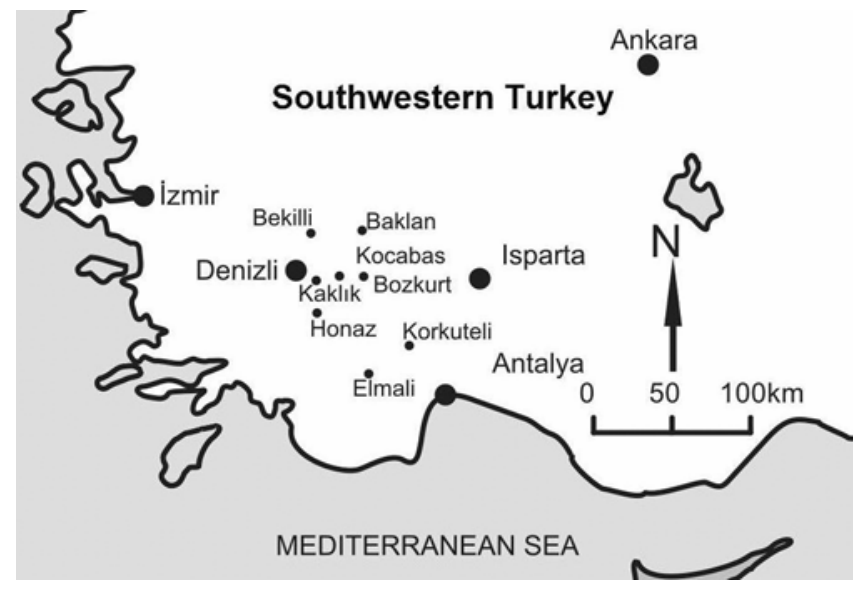

Figure 1. Sampling locations in the study area.

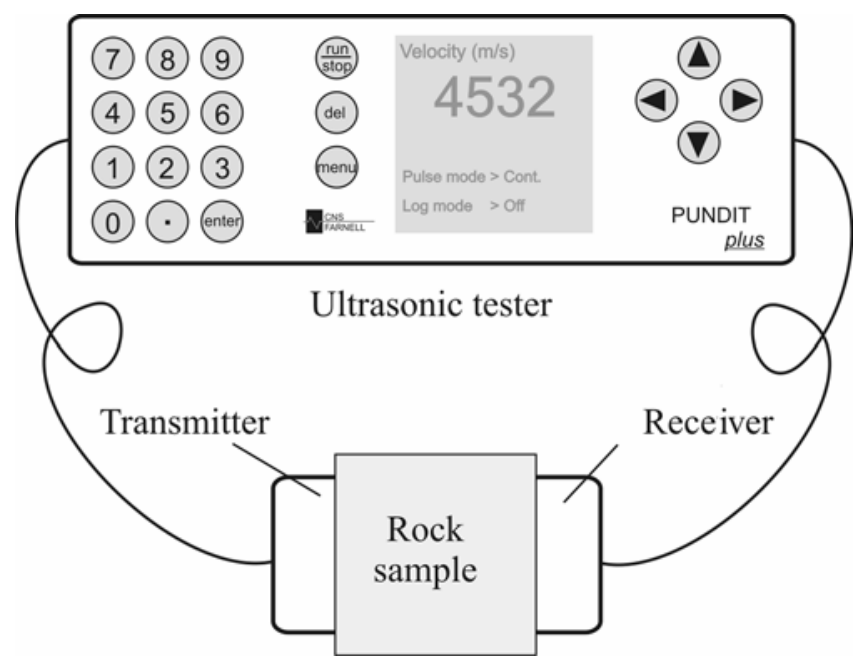

Figure 2. $P$-wave velocity apparatus utilized in this study. white coloured, fine grained spray-calcite cemented limestone outcrops around the City of Antalya (figures 3e and f). Dolomitic limestone is dark coloured, medium to coarse grained and massive in Eocene age (figure $3 \mathrm{~g}$ ). Two types of schist outcropped around the Denizli basin is categorized according to their mineralogical properties (figures $3 \mathrm{~h}$ and $\mathrm{i}$ ).

\section{Statistical analysis and discussions}

Using the linear and nonlinear regression techniques including simple or multiple analysis for predicting the unknown from known variables are commonly encountered in the literature (O'Rourke 1989; Cargill and Shakoor 1990; Kahraman 2001; Sharma and Singh 2007; Yagiz 2008, 2009a). In this study, to develop the sets of empirical equations between $V_{\mathrm{p}}$ and other rock properties including uniaxial compressive strength, modulus of elasticity, Schmidt hardness, slake durability index, effective porosity, water absorption by weight, and both saturated and dry density of rocks, linear and nonlinear simple regression analysis were performed with $95 \%$ confidence limits. To investigate the reliability of the obtained relationships, $t$-test and factor of significance ( $P$-value) test were conducted among the achieved equations using the SPSS version 15 (2007) statistical package. Set of equations developed between the $V_{\mathrm{p}}$ and measured rock properties using regression analysis are given in table 5 . The significance of $r$-value can be determined by various statistical tests such as $t$-test and $P$-value test that is also known as observed level of significance test $(\alpha)$. The $t$-test compares the computed values with tabulated values using null hypothesis (Levine et al 2001). According to the $t$-test, when computed $t$-value is greater than tabulated $t$-value, the null hypothesis is rejected and obtained correlation coefficient ( $r$-value) is acceptable. Also, observed level of significance is often used in hypothesis test. In this case, as $p$-value is smaller than level of significance $(\alpha=0.05)$, the null hypothesis is rejected. Therefore, it means that there is a relation between the correlated parameters and this shows that $r$-value is significant.

In this study, the result of the regression analysis indicates that $V_{\mathrm{p}}$ have reliable relationship with the E, UCS, $\mathrm{Hr}, n^{\prime}$, and water absorption by weight (figures 4-8) in accordance with the result of statistical analysis. On the other hand, the relation between $V_{\mathrm{p}}$ and $\mathrm{Id}_{2}$ is not strong

Table 3. $P$-wave velocity classification (Anon 1979).

\begin{tabular}{ll}
\hline$V_{\mathrm{p}}(\mathrm{km} / \mathrm{s})$ & Description \\
\hline$<2 \cdot 5$ & Very low \\
$2 \cdot 5-3 \cdot 5$ & Low \\
$3 \cdot 5-4 \cdot 0$ & Moderate \\
$4 \cdot 0-5 \cdot 0$ & High \\
$>5 \cdot 0$ & Very high \\
\hline
\end{tabular}



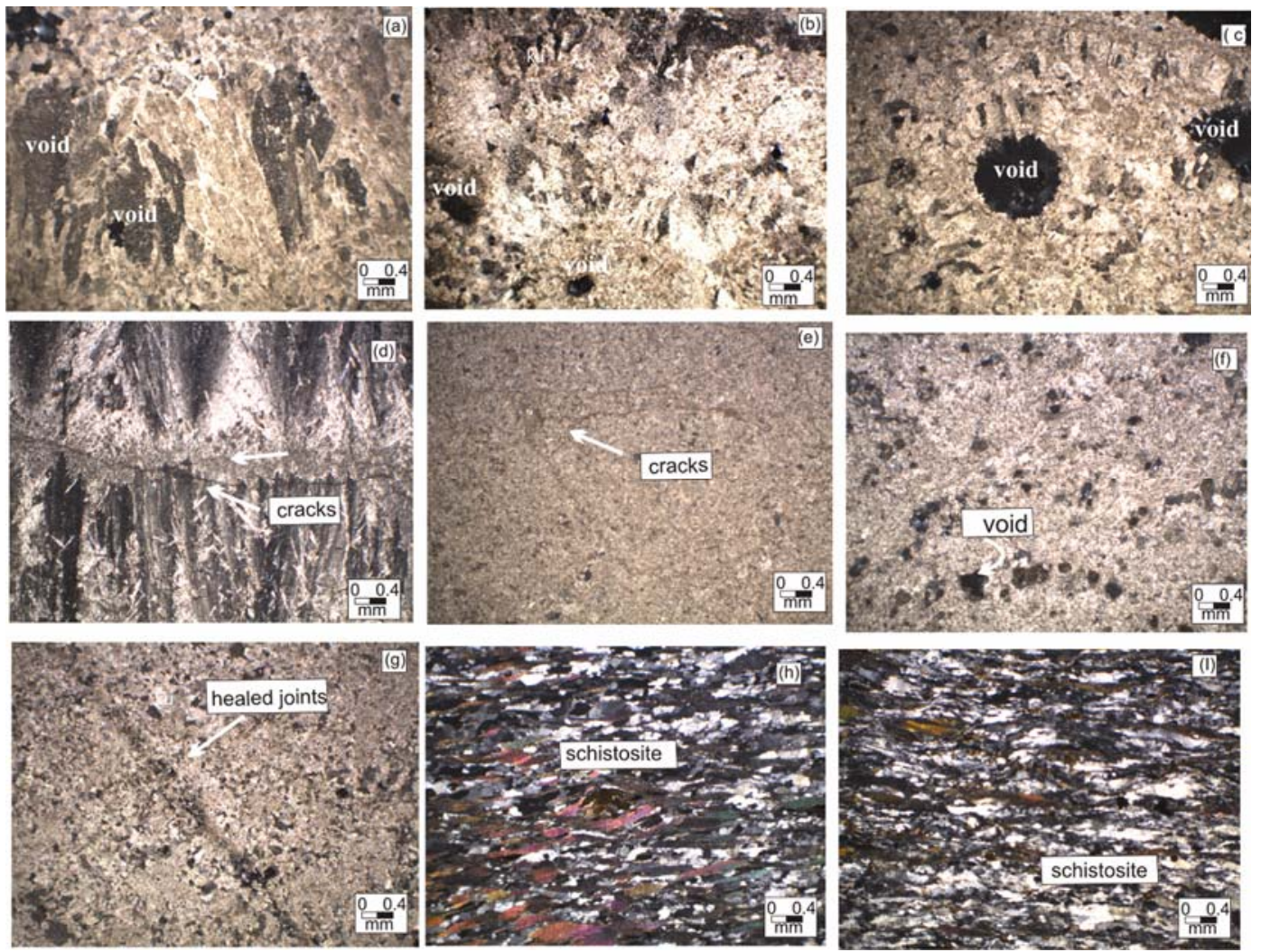

Figure 3. Mineralogical and textural studies of rock using thin section analysis $(\times 10)$; (a) Shrub travertine (b) Noche travertine (c) Reed travertine (d) Onyx travertine (e) Beige limestone (f) Soft limestone (g) Dolomitic limestone (h) Biotite schist (i) Muscovite schist.

Table 4. Mineralogical and petrographical composition of studied rocks together with location.

\begin{tabular}{|c|c|c|c|}
\hline $\begin{array}{l}\text { Rock type/ } \\
\text { lithology }\end{array}$ & Locations & Microscopic description & Grain size \\
\hline $\begin{array}{l}\text { Sedimentary/ } \\
\text { shrub travertine }\end{array}$ & $\begin{array}{l}\text { Denizli/ } \\
\text { Kocabas }\end{array}$ & $\begin{array}{l}\text { Sparite micrite cemented, densely packed texture, } \\
\text { crystals } 5-10 \mu \mathrm{m} \text { in size with no internal architecture }\end{array}$ & $\begin{array}{l}\text { Fine to fine } \\
\text { medium }\end{array}$ \\
\hline $\begin{array}{l}\text { Sedimentary/ } \\
\text { Noche travertine }\end{array}$ & $\begin{array}{l}\text { Denizli/ } \\
\text { Kocabas }\end{array}$ & $\begin{array}{l}\text { Sparite calcite cemented. Crystal size } 20 \mu \mathrm{m} \text { or more in dia; } \\
\text { compact texture with low pores and organic matter. }\end{array}$ & $\begin{array}{l}\text { Fine to } \\
\text { medium }\end{array}$ \\
\hline $\begin{array}{l}\text { Sedimentary/ } \\
\text { reed travertine }\end{array}$ & $\begin{array}{l}\text { Denizli/ } \\
\text { Kaklik }\end{array}$ & $\begin{array}{l}\text { Sparite calcite cemented, crystal size from } 20-150 \mu \mathrm{m} \text { in } \\
\text { diameter. Relatively more organic content and porous. }\end{array}$ & $\begin{array}{l}\text { Fine to } \\
\text { medium }\end{array}$ \\
\hline $\begin{array}{l}\text { Sedimentary/ } \\
\text { onyx travertine }\end{array}$ & $\begin{array}{l}\text { Denizli/ } \\
\text { Honaz }\end{array}$ & $\begin{array}{l}\text { Micrite and sparite cemented matrix, dark coloured. Sparry crystals } 10 \mu \mathrm{m} \\
\text { wide and } 100-200 \mu \mathrm{m} \text { in length with iron content, layered texture. }\end{array}$ & $\begin{array}{l}\text { Fine with } \\
\text { organic matter }\end{array}$ \\
\hline $\begin{array}{l}\text { Sedimentary/ } \\
\text { beige limestone }\end{array}$ & $\begin{array}{l}\text { Antalya/ } \\
\text { Korkuteli }\end{array}$ & $\begin{array}{l}\text { Sparite calcite cemented, micro crack observed with } \\
\text { coarse spar-calcite and calcite fillings, no fossils. }\end{array}$ & $\begin{array}{l}\text { Medium to } \\
\text { coarse }\end{array}$ \\
\hline $\begin{array}{l}\text { Sedimentary/ } \\
\text { dolomitic lime }\end{array}$ & $\begin{array}{l}\text { Denizli/ } \\
\text { Bozkurt }\end{array}$ & $\begin{array}{l}\text { Sparite and micrite cemented texture with healed } \\
\text { joints filled with secondary calcite fillings. }\end{array}$ & $\begin{array}{l}\text { Medium to } \\
\text { coarse }\end{array}$ \\
\hline $\begin{array}{l}\text { Sedimentary/ } \\
\text { white limestone }\end{array}$ & $\begin{array}{l}\text { Antalya/ } \\
\text { Elmali }\end{array}$ & $\begin{array}{l}\text { Sparite calcite cemented, light cream coloured, } \\
\text { some micro fossils with no cracks. }\end{array}$ & Fine grain \\
\hline $\begin{array}{l}\text { Meta-sedimentary/ } \\
\text { quartz-biotite-schist }\end{array}$ & $\begin{array}{l}\text { Denizli/ } \\
\text { Bekilli }\end{array}$ & $\begin{array}{l}\text { Crystal size } 0 \cdot 1-0 \cdot 2 \mathrm{~mm} \text {, elongated calcite and quartz crystals } \\
\text { along the schistose, quartz biotite, mica schist with opaque } \\
\text { and schistose texture. }\end{array}$ & $\begin{array}{l}\text { Fine to } \\
\text { medium fine }\end{array}$ \\
\hline $\begin{array}{l}\text { Meta-sedimentary/ } \\
\text { quartz-mica-schist }\end{array}$ & $\begin{array}{l}\text { Denizli/ } \\
\text { Baklan }\end{array}$ & $\begin{array}{l}\text { Crystal size } 0 \cdot 1-0 \cdot 2 \mathrm{~mm} \text {, elongated calcite and quartz crystals along } \\
\text { the schistose, quartz muscovite, schist with opaque and schistose texture. }\end{array}$ & $\begin{array}{l}\text { Fine to } \\
\text { medium fine }\end{array}$ \\
\hline
\end{tabular}


Table 5. Empirical equations between $V_{\mathrm{p}}$ and the measured rock properties.

\begin{tabular}{|c|c|c|c|c|c|}
\hline Rock properties & Equations & $r$-value & $t$-value & $t$-table & $P$-value $<\alpha=0.05$ \\
\hline$E(\mathrm{GPa})$ & $E=20 \cdot 1 \cdot V_{\mathrm{p}}-53$ & $0 \cdot 95$ & $8 \cdot 22$ & $\pm 2 \cdot 31$ & $0 \cdot 000$ \\
\hline $\mathrm{UCS}(\mathrm{MPa})$ & $\mathrm{UCS}=49 \cdot 4 \cdot V_{\mathrm{p}}-167$ & $0 \cdot 89$ & $5 \cdot 22$ & $\pm 2 \cdot 31$ & $0 \cdot 001$ \\
\hline$n^{\prime}(\%)$ & $n^{\prime}=-5 \cdot 19 \cdot V_{\mathrm{p}}+27 \cdot 1$ & $0 \cdot 86$ & $-4 \cdot 53$ & $\pm 2 \cdot 31$ & $0 \cdot 003$ \\
\hline$w(\%)$ & $w=-2 \cdot 23 \cdot V_{\mathrm{p}}+11 \cdot 6$ & $0 \cdot 85$ & $-4 \cdot 30$ & $\pm 2 \cdot 31$ & $0 \cdot 004$ \\
\hline $\mathrm{Hr}$ & $\mathrm{Hr}=11 \cdot 68 \cdot V_{\mathrm{p}}-6 \cdot 64$ & $0 \cdot 80$ & $3 \cdot 55$ & $\pm 2 \cdot 31$ & 0.009 \\
\hline $\mathrm{Id}_{2}$ & $\mathrm{Id}_{2}=0.71 \cdot V_{\mathrm{p}}+95 \cdot 7$ & $0 \cdot 69$ & $2 \cdot 12$ & $\pm 2 \cdot 31$ & $0 \cdot 088$ \\
\hline$\rho_{\text {dry }}\left(\mathrm{g} / \mathrm{cm}^{3}\right)$ & $\rho_{\text {dry }}=0 \cdot 19 \cdot V_{\mathrm{p}}+1 \cdot 61$ & $0 \cdot 58$ & 1.85 & $\pm 2 \cdot 31$ & $0 \cdot 107$ \\
\hline$\rho_{\text {sat }}\left(\mathrm{g} / \mathrm{cm}^{3}\right)$ & $\rho_{\text {sat }}=0 \cdot 14 \cdot V_{\mathrm{p}}+1 \cdot 88$ & 0.46 & $1 \cdot 40$ & $\pm 2 \cdot 31$ & $0 \cdot 206$ \\
\hline
\end{tabular}

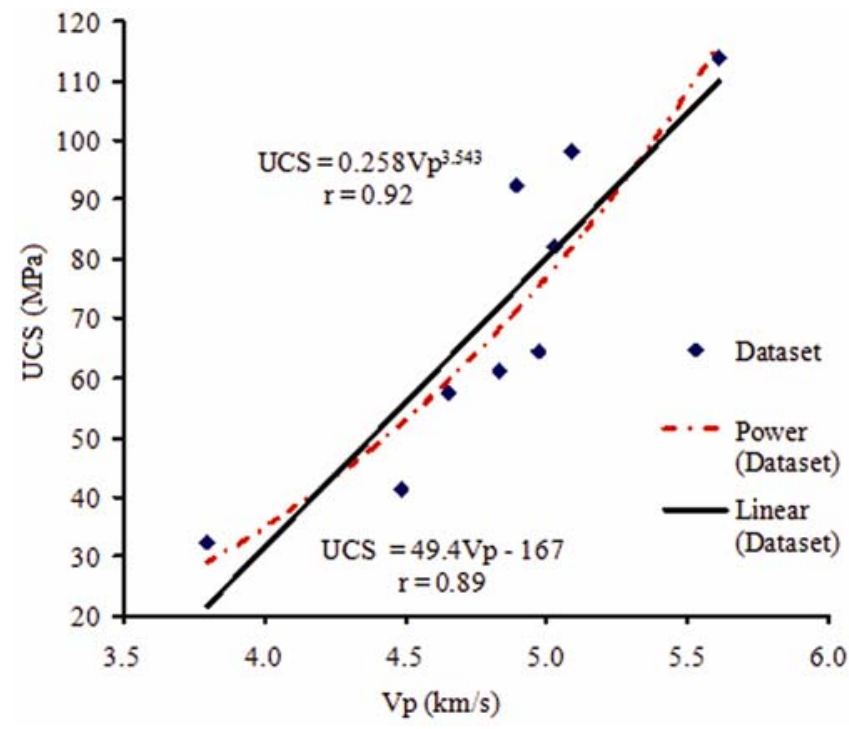

Figure 4. Relationship between the UCS and $V_{\mathrm{p}}$.

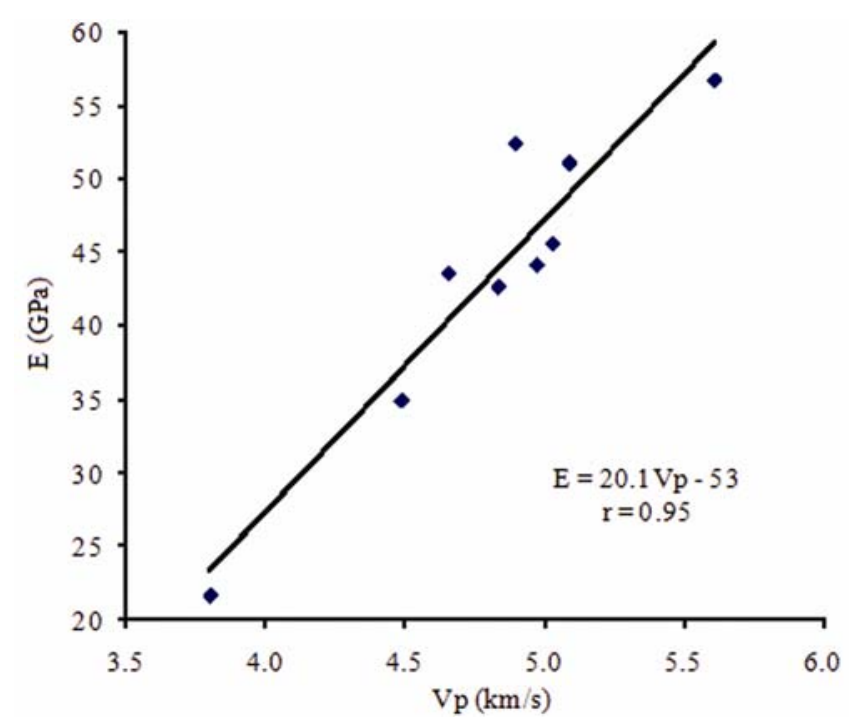

Figure 5. Relationship between the $E$ and $V_{\mathrm{p}}$.

enough to rely on $(r=0.69)$ as given in figure 9 . Further, the $V_{\mathrm{p}}$ provides lower relationship with dry and saturated

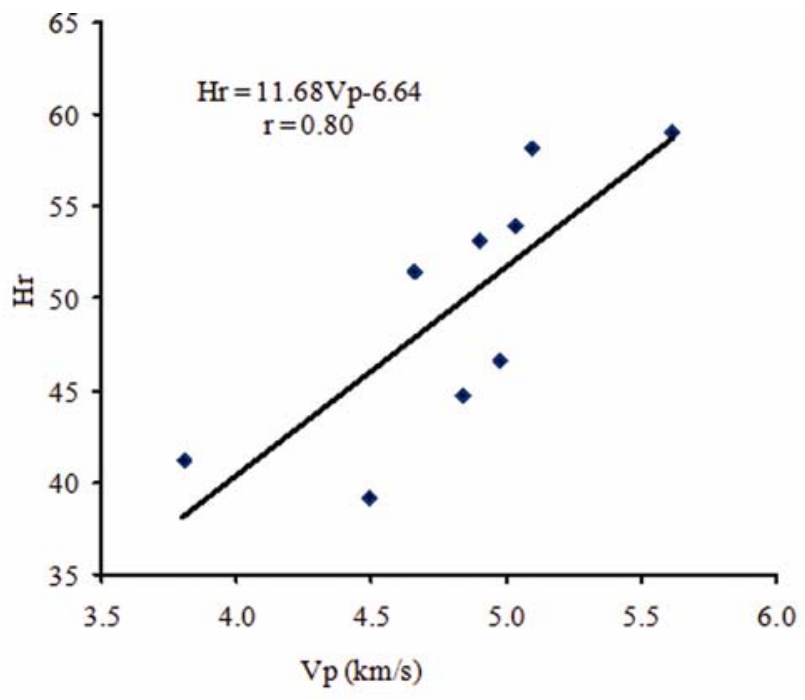

Figure 6. Relationship between the $\mathrm{Hr}$ and $V_{\mathrm{p}}$.

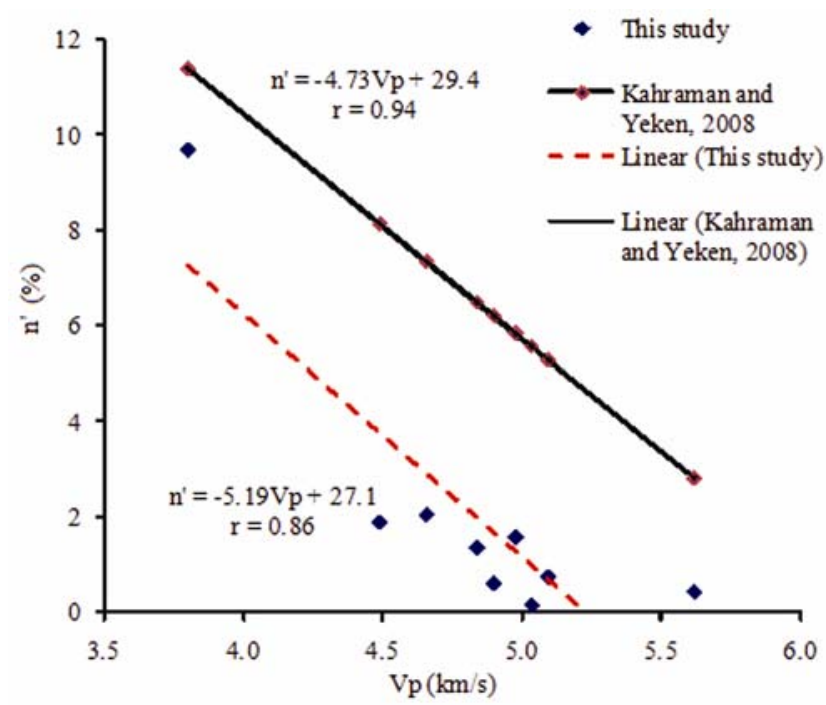

Figure 7. Relationship between the $n^{\prime}$ and $V_{\mathrm{p}}$.

density of rock with $r=0.58$ and 0.46 respectively (figure 10). To evaluate the validity of the generated equations between the rock properties and $P$-wave velo- 
city, obtained empirical equations are compared with those equations available in the literature. The relationship between $V_{\mathrm{p}}$ and rock properties including effective porosity, water absorption by weight and slake durability index

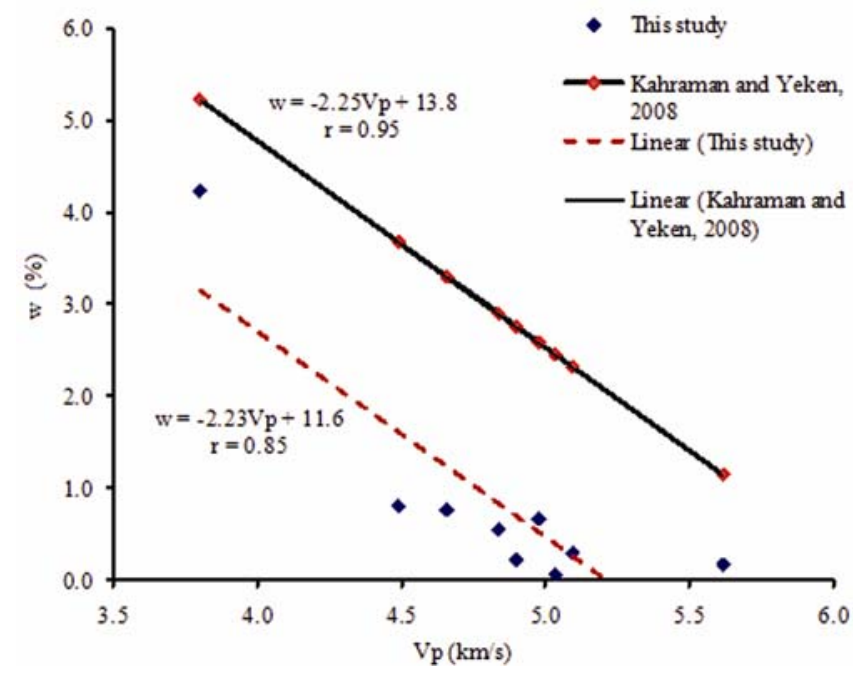

Figure 8. Relationship between the $w$ and $V_{\mathrm{p}}$.

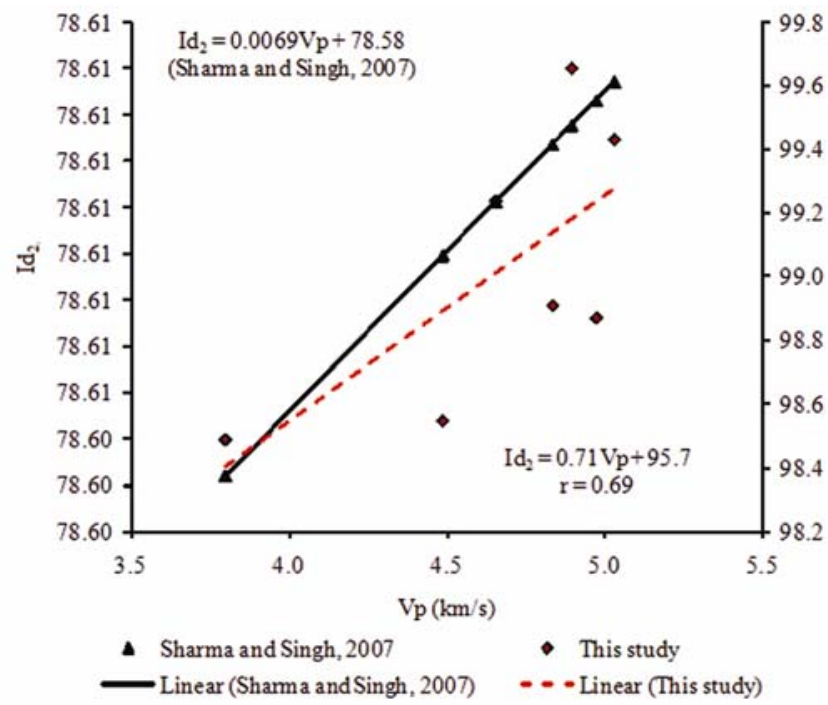

Figure 9. Relationship between $\mathrm{Id}_{2}$ and $V_{\mathrm{p}}$ together with previous study from literature.

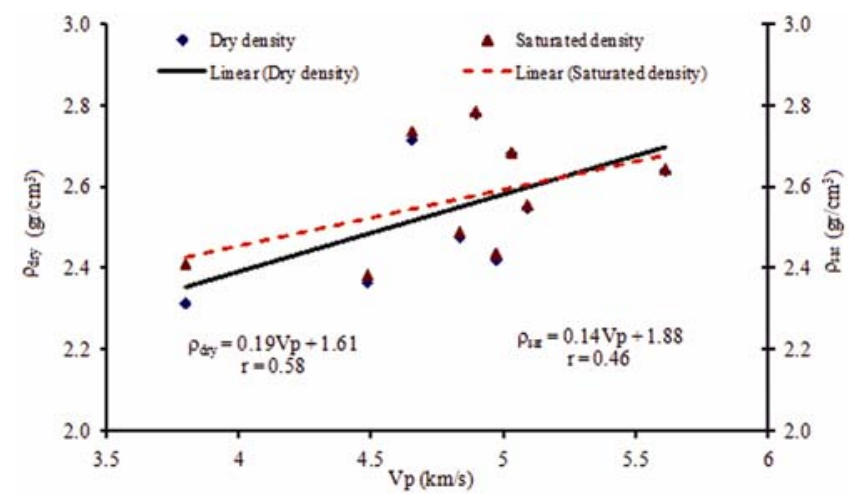

Figure 10. Relationship between both the $\rho_{\text {dry }}$ and $\rho_{\text {sat }}$ with $V_{\mathrm{p}}$. are compared with the previous studies in figures 7-9. Further, produced empirical relationship between $V_{\mathrm{p}}$ and both UCS and dry density of rocks are also associated with previous researches in figures 11 and 12 . As seen from the figures $7-12$, the obtained equations and coefficient of correlations are various ranging from 0.46 to $0 \cdot 95$.

\section{Conclusions}

Using the standard testing methods, nine different rock types were tested and the results examined to generate

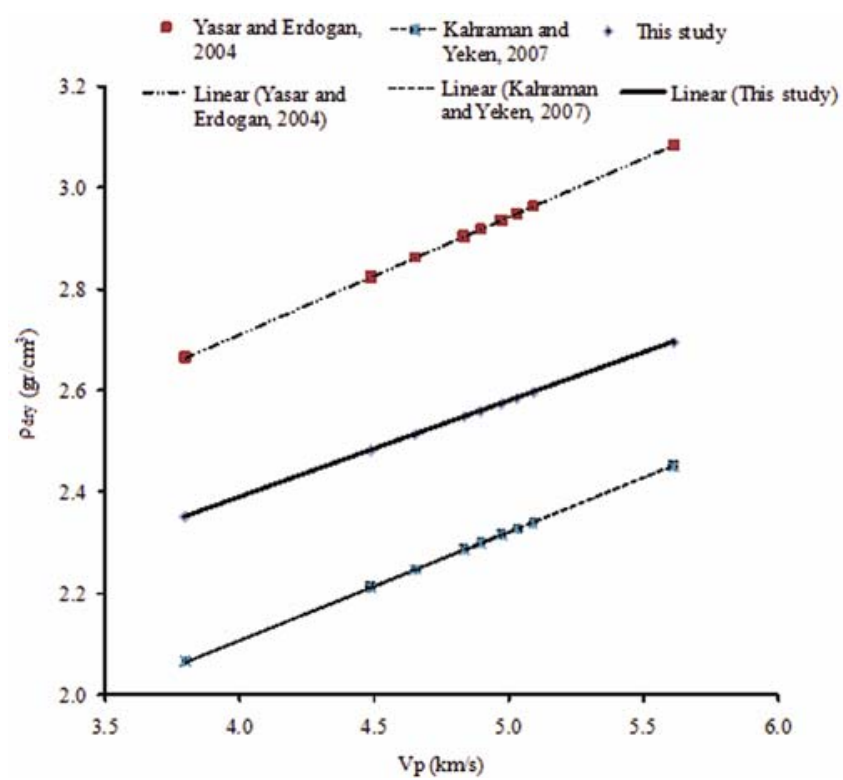

Figure 11. Comparison of the obtained results with previous researches; $\rho_{\text {dry }}$ vs $V_{\mathrm{p}}$.

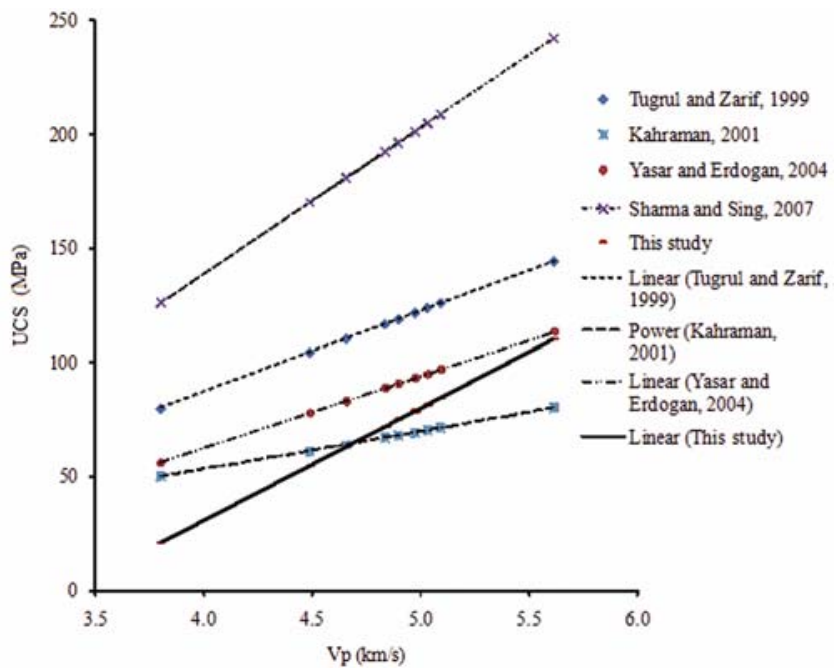

Figure 12. Comparison of the obtained results with previous researches; UCS vs $V_{\mathrm{p}}$. 
empirical relationship between $V_{\mathrm{p}}$ and rock properties including uniaxial compressive strength, modulus of elasticity, Schmidt hardness, slake durability index, effective porosity, water absorption by weight and both dry and saturated density of rocks. Further, petrographical and mineralogical studies were conducted using thin section analysis. It is evident that rock texture and type have great affect on their geotechnical properties. The result shows that the UCS, E, Hr, $n^{\prime}, w$ and $\mathrm{Id}_{2}$ of rocks can be estimated by conducting $V_{\mathrm{p}}$ test that is non-destructive, simple, faster and a relatively economic method for rock characterization. The best relationships obtained between the $V_{\mathrm{p}}$ and both UCS and E were with correlation coefficient of 0.92 and 0.95 , respectively. The relationship between the $V_{\mathrm{p}}$ and measured rock properties are acceptable according to the statistical analysis including $t$-test, $p$-value test and coefficient of correlations except that obtained between the $V_{\mathrm{p}}$ and both dry and saturated unit weight of rock $(r=0.58$ and 0.46 , respectively). The investigated rock properties excluding dry and saturated density of rock can be estimated as function of $V_{\mathrm{p}}$ using derived equations; however, those equations should be used with care for only similar rocks.

\section{Acknowledgement}

Thanks are due to Drs Mehmet Ozkul and Tamer Koralay, Pamukkale University, for thin section analysis.

\section{References}

Anon 1979 Bull. Int. Ass. Eng. Geol. Bull. 19364

Boadu F K 1997 J. Appl. Geophys. 361

Cargill J S and Shakoor A 1990 Int. J. Rock Mech. Min Sci. 27 495

Chafetz H S and Folk R L 1984 J. Sediment. Petrol. 54289
EN 2000a European committee for standardization. TS EN 192610

EN 2002b European committee for standardization. TS EN 124074

Gladwin M T 1982 Int. J. Rock Mech. Min. Sci. 19221

Guo L and Riding R 1998 Sedimentology 45163

Hawkins A B and McConnell B J 1992 Q. J. Eng. Geol. 25 115

Hudson J A, Jones E T W and New B M 1980 Q. J. Eng. Geol. 1333

International Society for Rock Mechanics 1981 ISRM Suggested Methods. 211

Kahraman S 2001 Int. J. Rock Mech. Min. Sci. 38981

Kahraman S and Yeken S 2008 Bull. Eng. Geol. Environ. 67 277

Karpuz C and Pasamehmetoglu A G 1997 Eng. Geol. 461

Lama R D and Vutukuri VS 1978 Handbook on mechanical properties of rocks (Germany) Vol. 2.

Levine D M, Ramsey P P and Smidt R K 2001 Applied statistics for engineers and scientists, p. 670

Onodera TF 1963 5th US Symposium on rock mechanics p. 517

O’Rourke J E 1989 Min. Eng. 41106

SPSS 2007 Statistical package for the social sciences (Chicago IL USA: V15.0

Sharma P K and Singh T N 2007 Bull. Eng. Geol. Environ. 67 17

Thill R E and Bur T R 1969 Geophysics 34101

Tugrul A and Zarif H 1999 Eng. Geol. 51303

Turk N and Dearman W R 1986 27th US Symposium on rock mechanics 168

Ulusay R, Tureli K and Ider M H 1994 Eng. Geol. 37135

Yagiz S 2010 Scient. Res. Essays 5750

Yagiz S 2009 Bull. Eng. Geol. Environ. 6855

Yagiz S 2009a Tunn Underground Space Tech. 2466

Yagiz S 2008 Tunn Underground Space Tech. 23326

Yasar E and Erdogan Y 2004 Int. J. Rock Mech. Min. Sci. 41 871

Young R P, Hill T T, Bryan I R and Middleton R 1985 Quart. J. Eng. Geol. 18459 